\title{
Squamous Cell Carcinoma In Situ of the Nipple
}

National Cancer Institute

\section{Source}

National Cancer Institute. Squamous Cell Carcinoma In Situ of the Nipple. NCI Thesaurus.

Code C28292.

An intraepidermal squamous cell carcinoma involving the area of the nipple. -- 2003 